\title{
Lung cancer-initiating cells: a novel target for cancer therapy
}

\author{
Brian J. Morrison • John C. Morris • Jason C. Steel
}

Received: 9 November 2012 / Accepted: 20 December 2012 /Published online: 15 January 2013

(C) The Author(s) 2013. This article is published with open access at Springerlink.com

\begin{abstract}
Lung cancer is a major public health problem causing more deaths than any other cancer. A better understanding of the biology of this disease and improvements in treatment are greatly needed. Increasing evidence supports the concept that a rare and specialized population of cancer cells, so-called cancer-initiating cells with stem cell-like characteristics, is responsible for tumor growth, maintenance, and recurrence. Cancer-initiating cells also exhibit characteristics that render them resistant to both radiation and chemotherapy, and therefore they are believed to play a role in treatment failure. This has led to the hypothesis that traditional therapies that indiscriminately kill tumor cells will not be as effective as therapies that selectively target cancer-initiating cells. Investigating putative cancer-initiating cells in lung cancer will greatly benefit the understanding of the origins of this disease and may lead to novel approaches to therapy by suggesting markers for use in either further isolating this population for study or for selectively targeting these cells. This review will discuss (1) lung cancer, (2) stem cells, and the role of cancerinitiating cells in tumorigenesis; (3) markers and functional characteristics associated with lung cancer-initiating cells; and (4) the potential to selectively target this subpopulation of tumor cells.
\end{abstract}

Keywords Lung $\cdot$ Cancer $\cdot$ Cancer-initiating cells $\cdot$ Stem cells $\cdot$ Self-renewal $\cdot$ Targeted therapy $\cdot$ Immunotherapy

B. J. Morrison · J. C. Morris · J. C. Steel

Division of Hematology-Oncology, Department of Medicine,

University of Cincinnati, Cincinnati, OH 45267, USA

B. J. Morrison $(\square)$

Division of Hematology-Oncology, Vontz Center for Molecular

Studies, Department of Internal Medicine,

University of Cincinnati, 3125 Eden Ave., M/L 0508,

Cincinnati, OH 45267, USA

e-mail: morrisb7@uc.edu

\section{Lung cancer and cancer-initiating cells}

Lung cancer is the leading cause of cancer-related deaths worldwide [1]. Despite recent advances in treatment, the overall survival of patients with lung cancer remains only $15 \%$ at 5 years, and this declines to less than $2 \%$ in patients with metastatic disease [2]. For patients with advanced small cell lung cancer (SCLC), disease survival is 1-2\% [3]. Patients who respond to initial treatment often relapse and succumb to chemotherapy-resistant tumors [4]. This familiar clinical scenario is not restricted to lung cancer, but occurs in several hematological and solid tumors. Hence, new treatments that specifically target chemotherapy-resistant cells are needed.

The majority of solid tumors are composed of a heterogeneous population of cells including a proportion of cells that are innately chemotherapy-resistant or have gained resistance through acquired mutations (reviewed in [5]). As a result, chemotherapy predominantly kills the drugsensitive cells, leaving behind a heterogeneous population of resistant cells, including those that have the potential to re-populate the tumor or seed new metastatic sites. These cells are putative cancer-initiating cells (CICs). We believe that under the selective pressure of chemotherapy the CICs, which are innately chemo-resistant, are able to produce progenitor cells which are also resistant to chemotherapy leading to the development of a treatment resistant tumor. Evidence for this can be seen in chemotherapy resistant tumors which have an acquired increased expression of the multi-drug resistance genes (e.g., MDR1), which encode for drug efflux pumps. These pumps are highly expressed in CICs and are thought to be a major factor in their innate drug resistance [6].

The concept of a specialized population of cells within tumors termed CICs, or alternatively cancer stem cells or tumor-initiating cells, has received considerable recent 
interest. CICs represent a subpopulation of transformed cells, distinct from more "differentiated" tumor cells, and are thought to be responsible for tumor organization, maintenance and progression, and resistance to therapy. CICs display functional characteristics of stem cells such as the capacity for self-renewal and the ability to give rise to differentiated progeny responsible for tumor proliferation. Putative CICs have been identified in acute myeloid leukemia (AML) [7, 8], and solid tumors of the brain $[9,10]$ and breast [11], among others. More recently, lung CICs have been isolated from human cell lines and patient samples [12-19]. CICs are posited to share many of the properties of normal somatic stem cells.

\section{Stem cells and the role of CICs in tumorigenesis}

Normal somatic stem cells have the following attributes: (1) they are capable of self-renewal and repair in adult tissues; (2) they have the capacity for differentiation and the ability to generate a large number of multi-lineage progeny; (3) they are normally quiescent, but can be activated and proliferate in response to various stimuli to maintain tissue homeostasis; and (4) they have flexibility in applying these characteristics [20]. Somatic stem cells reside at the top of a hierarchy of tissue cells. Downstream of the stem cells is the more differentiated and rapidly proliferating progenitor/transit-amplifying cell progeny. Progenitor cells are capable of differentiating into mature cells of various lineages. Differentiated cells are specialized for specific roles and make up the bulk of the tissue.

Under the appropriate conditions, stem cells may undergo either asymmetrical division, to give rise to one transitamplifying cell and another stem cell, or symmetrical division, to give rise to two stem cells or two transit-amplifying cells [20]. Asymmetric division provides continuation of the stem cell compartment while also producing the starting material for production of differentiated cells. Symmetric division provides flexibility during homeostasis: producing two stem cells or two transit-amplifying cells may either increase or decrease the stem cell pool depending on the needs of the system [21]. It has been suggested that the stem cell environment or niche may alter the stem cell pool by influencing how the stem cell divides and the plasticity of these cells [22]. The lung has a hierarchical organization that is thought to be regulated through the presence and activity of lung stem cells [23].

CICs are cancerous cells with many similar attributes as somatic stem cells including (1) self-renewal capacity, (2) the ability to differentiate and produce multi-lineage progeny that are tumorigenic and non-tumorigenic, (3) the capacity to establish and maintain tumors, and (4) flexibility in the application of these processes. Both cell types are long-lived and exhibit telomerase activity and active anti-apoptotic pathways [24]. Somatic stem cells and CICs demonstrate resistance to toxins and chemotherapeutics, often as a result of expression of the ATP-binding cassette (ABC) membrane transporter proteins $[15,25]$, and are believed to be relatively resistant to radiation due to their low proliferative indexes. Stem cells and CICs are also motile, thus allowing migration and homing of somatic stem cells, and metastatic spread for CICs [26]. Additionally, both somatic stem cells and tumors/ CICs have niches - surrounding environments where bidirectional interactions between somatic stem cells/CICs occur that help maintain them.

The origins of CICs are largely unknown (reviewed in [27]). It has been posited that normal stem cells that have undergone mutational events leading to a loss of self-renewal control are the source of CICs, or that transit-amplifying or differentiated cells that have undergone "de-differentiation," acquired a self-renewal capacity, and lost regulation of cellular division could be the source of CICs (Fig. 1a). The similarity between somatic stem cells and CICs suggests that fewer steps might be involved for stem cells to transform into CICs compared to transit-amplifying or differentiated cells, which need to gain stem cell-like characteristics. However, the rarity of stem cells and the relative quiescent nature of somatic stem cells would suggest that they may be less likely to accumulate oncogenic mutations compared to transit-amplifying cell progeny. Regardless of the origin of CICs, they can be identified and isolated based on certain characteristics.

Self-renewal pathways and stemness genes associated with CICs

One critical step in the transformation of a normal cell into a CIC is the acquisition of unregulated self-renewal. This is often associated with changes in the signaling pathways of Hedgehog (Hh), Notch, and Wnt/ $\beta$-catenin, and/or the activation of "stemness" genes such as Oct-4, Nanog, Sox-2, or bone morphogenetic proteins (BMPs). Signaling pathways involved in maintaining CICs self-renewal or "stemness" may represent potential targets for cancer therapy.

The Hedgehog/Patched pathway is involved in embryonic growth and cell fate determination. During lung development, Hh signaling plays a role in lung bud branching morphogenesis [28]. Hh signaling has been implicated in regulating self-renewal of hematopoietic stem cells [29] and myeloid leukemia cells [30], as well as tumor cells in several solid tumors. Hh overexpression may lead to uncontrolled proliferation of tissue stem cells, generating a pool of target cells for additional oncogenic events leading to acquisition of CICs. Alterations in the Hh pathway have been reported in a variety of cancers including medulloblastoma, glioma, stomach, colon, pancreatic cancer, basal cell carcinoma, rhabdomyosarcoma, breast, prostate, and lung cancer [31]. 


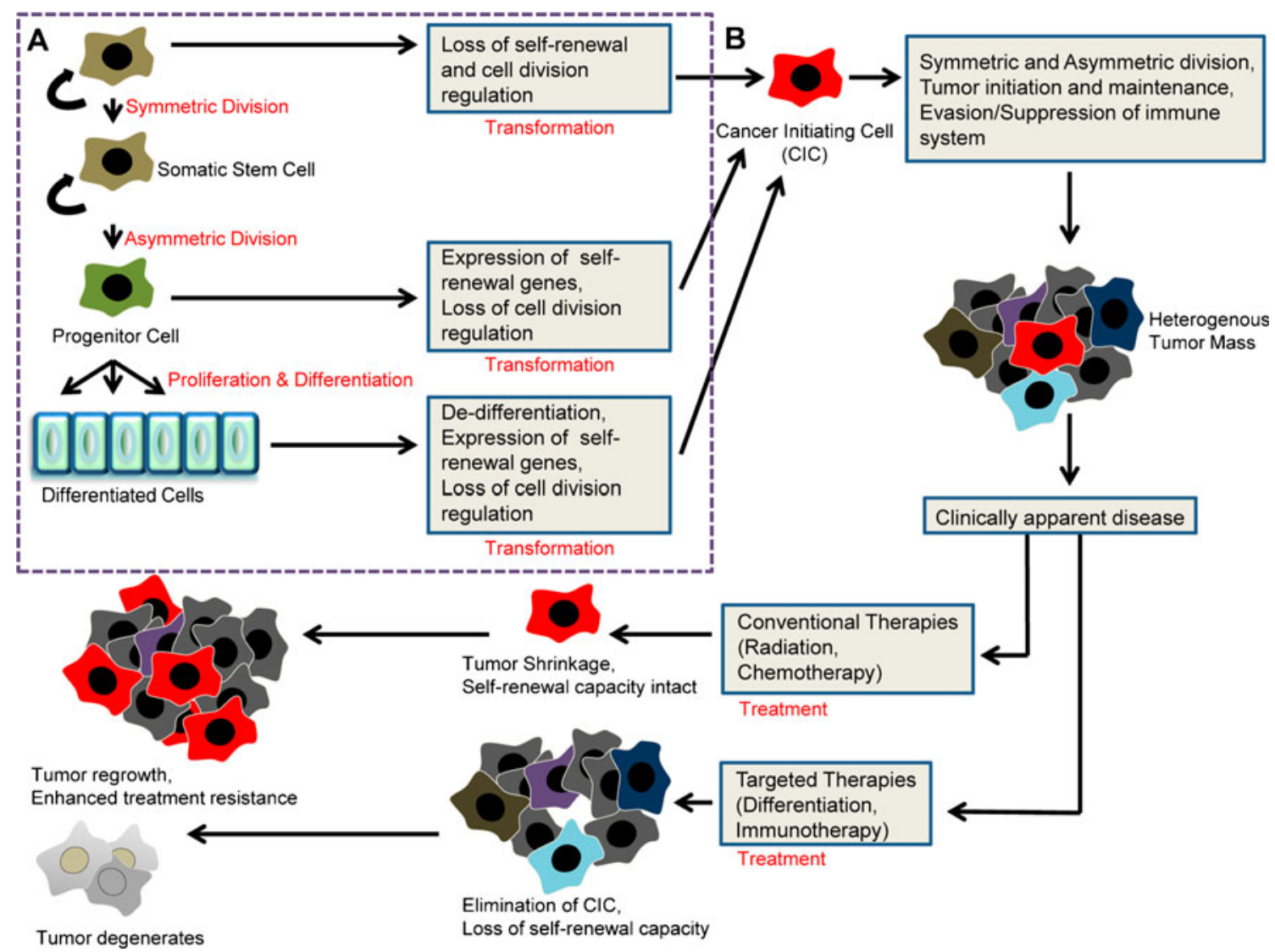

Fig. 1 Origins of cancer-initiating cells and conventional therapy versus cancer-initiating cell targeted therapy. a CICs may be derived from somatic stem cells, progenitor cells, or differentiated cells. Somatic stem cells may require fewer transformational events than other cell types to become CICs. These events might include loss of regulation of self-renewal pathways and/or loss of cell division control. Somatic stem cells can undergo symmetric division to generate two stem cells, or asymmetric division to generate one stem cell and one progenitor cell. Progenitor cells may undergo a transforming event involving re-expression of self-renewal genes and a subsequent loss of cell division regulation to become CICs. Progenitor cells provide the starting material for proliferation and differentiation of cells into several lineages of differentiated cells. In order to generate a CIC,

The Notch family of transmembrane signaling proteins (Notch-1, -2, -3, and-4) regulate cell fate and are expressed in stem cells and transit-amplifying cells [32]. Notch signaling activation, via Jagged-1, is involved in the maintenance of self-renewal and plasticity for hematopoietic stem cells [33]. Inappropriate activation of Notch signaling stimulates proliferation, restricts differentiation and prevents apoptosis in cancer cells, and is associated with a variety of human cancers including breast, neuroblastoma, cervical, and lung [34]. Additionally, Notch signaling has been shown to preserve lung somatic stem cells in an undifferentiated state inhibiting terminal epithelial differentiation $[35,36]$.

The Wnt pathway is involved in cell fate determination in many organs during embryonic development. The Wnt pathway involves a large number of proteins in a cascade differentiated cells may undergo de-differentiation with re-expression of self-renewal genes and loss of regulation of cell division. b CICs form and maintain a heterogeneous tumor through rounds of asymmetric and symmetric division and through suppressing or evading host immune responses. Treatment typically begins soon after clinically apparent disease is detected. Conventional therapies that target differentiated cells, but spare CICs allow initial debulking of the tumor. However, tumor ultimately recurs because the rare therapy-resistant CICs have not been eliminated. These recurrences are often not responsive to subsequent treatment. Conversely, therapies that target CICs, but spare differentiated cells, do not appear to greatly debulk the tumor early on. However, as the CIC pool has been eliminated, the tumor can no longer maintain itself and ultimately degenerates

that ultimately leads to controlling the amount of $\beta$-catenin that reaches the nucleus to activate gene expression. Wnt signaling has been shown to regulate self-renewal in stem cells [37]. Evidence from transgenic mouse models demonstrated Wnt signaling pathway activation in stem cells leading to epithelial cancers [38]. Additionally, a pro-oncogenic role for $\beta$-catenin, a downstream target of Wnt signaling, has been described [39]. Drawn together, this indicates the involvement of Wnt signaling pathway members in the deregulation of stem cells into CICs. Evidence has emerged that Wnt signaling may play a role in lung tumorigenesis [40].

Induced stem cells are somatic cells that have been reprogrammed through forced expression of specific genes to obtain pluripotent stem cell-like characteristics [41]. This has led to the identification of "stemness" genes/transcriptional 
regulators involved in this process including c-myc, Klf4, Nanog, BMPs, Sox-2, and Oct-4. Sox-2 and Oct-4 in particular are involved in regulating self-renewal and pluripotent potential in stem cells and CICs. Enhanced expression of these genes, often in association with other functional/phenotypic markers or characteristics, has been used to characterize CICs from non-CICs in lung cancer [12-14, 17-19, 42].

\section{Biological markers and functional characteristics of lung CICs}

Various biological markers have been used for isolating and characterizing lung CICs. These include (1) cell surface markers such as CD133 and CD44; (2) phenotypic characteristics such as exclusion of Hoechst 33342 dye (side population) and aldehyde dehydrogenase 1 (ALDH1) activity; and (3) functional characteristics such as chemo- or radiotherapy resistance, growth as spheroids in serum-free medium, and tumor initiation in vivo (see Table 1). These characteristics are often used in concert (in addition to demonstrating activation of self-renewal pathways and stemness genes) to isolate and identify putative lung CIC populations.

\section{CIC cell surface markers: CD133 and CD44}

CD133 (prominin-1) is a five-transmembrane glycoprotein initially identified as a marker for isolating CD34+ human hematopoietic progenitor cells [43, 44]. CD133 has subsequently been used to identify and isolate somatic stem/ progenitor cells of neural [45], epithelial [46], and endothelial origin [47], as well as their putative corresponding CICs $[10,14,48-51]$. The function of CD133 has not been well described and its ligand is currently unknown. It has been reported that CD133 may play a role in cell cycle regulation and proliferation of cells, but not necessarily tumor initiation [52]. CD133 has been used as a marker to examine lung CICs. In a study assessing CD133 in lung cancer cells from patients and cell lines, Chen et al. demonstrated higher expression of Oct-4 in CD133+ cells compared to CD133cells [13]. In that study, Oct-4 expression was demonstrated to be essential for maintaining stem cell-like properties such as self-renewal capacity and invasiveness. Compared to CD133 - cells, CD133+ cells were also reported to have enhanced resistance to conventional treatments and increased in vivo tumor-restoration capacity and proliferation. Eramo et al. demonstrated that CD133+ cells isolated from patient lung cancer samples can grow as tumorspheres and have a tumorigenic potential that is lost upon differentiation into CD133- cells [14]. In that study, the expression of CD133 ranged between $0.32 \%$ and $22 \%$ of tumor cells. $\mathrm{CD} 133+$ cells have been reported to have a low frequency in normal lung cells $(<1 \%)$ while a relatively high, but variable, frequency in most lung cancer samples; 47 out 56 primary lung cancer tissue samples demonstrated CD133 expression ranging from $0.02 \%$ to $35 \%$ [12]. Cells expressing CD133 have been described as having a self-renewal capacity, cisplatin resistance in vitro and in vivo, enhanced expression of stemness-related markers (Oct-4 and Nanog), and greater tumorigenicity [12]. However, CD133 is likely not a universal marker for all lung CICs. Leung et al. did not detect CD133 in nine out of 10 human non-small cell lung cancer (NSCLC) cell lines with an ability to induce tumors in immunocompromised mice [17]. Similarly, Meng et al. demonstrated that both CD133+ and CD133- subpopulations of two human lung cancer cell lines both contained CICs, calling into question the exclusive reliance on this marker [53].

CD44 is a cell membrane receptor glycoprotein that binds hyaluronic acid, is involved in cell adhesion, motility, and metastases, and, along with P-glycoprotein, has been linked to multi-drug resistance [54]. CD44 expression has been associated with up-regulation of other cancer-associated factors such as transforming growth factor-beta (TGF- $\beta$ ), genes associated with WNT signaling, cell adhesion molecules, and chemokines $[55,56]$. CD44 can affect cell proliferation through its actions as a co-receptor with EGFR and ErbB family receptor tyrosine kinases [57]. Additionally, CD44 has been linked to enhancing anti-apoptosis through the PI3K/AKT cascade [58]. CD44 expression has been associated with human NSCLC cells enriched for CIClike properties [17]. Using ten human NSCLC cancer cell lines, Leung et al. have shown that $\mathrm{CD} 44+$ cells have enhanced CIC properties compared to CD44- cells, including enhanced spheroid formation in vitro [17]. Enhanced in vivo tumor initiation compared to CD44- cells was shown for sorted CD44+ cells from the H1299, HKULC4, H1650, and HCC 827 cell lines, with as few as 10,000 cells being capable of tumor initiation by days 30-68, compared to no tumors formed from the CD44- cells by day 90. For H1299 cells, CD44+ or unsorted cells were shown to have enhanced cisplatin resistance compared to CD44- cells. CD44+ cells, either freshly sorted or from CD44+-initiated tumors, showed expression of pluripotency/stemness genes (OCT4, NANOG, SOX2) not expressed by CD44- cells. However, CD44 expression was only detected in six of 10 cell lines examined [17], calling into question the exclusive reliance on this marker. The heterogeneity of CIC cell surface markers between tumors has led to the investigation of functional markers to identify CICs.

Functional markers of lung CICs: side population and ALDH1 activity

A functional marker is a physical marker that can be used to target or isolate the CIC and is associated with a functional characteristic of CICs. One functional characteristic 
Table 1 Functional characteristics and markers for human lung cancer-initiating cells

CIC-related characteristics

Functional characteristic

Sphere growth in

serum-free medium

Chemoresistance

Cell surface marker

CD133 (AC133, Prominin 1)

CD44

Phenotypic marker

ABCG2 activity (side population expression)

Aldehyde dehydrogenase 1 (ALDH1) activity
Sphere growth from 7/19 patient lung tumor samples (SCLC and NSCLC) with varying frequency of CD133+ expression $(0.6 \%$ to $22.0 \%$ of tumor cells that were capable of forming spheres). CD133+ lung cancer spheres demonstrated (1) expression of stemness genes such as OCT4 and NANOG, (2) self-renewal potential, (3) proliferation and differentiation ability (with subsequent loss of tumorigenic potential upon differentiation), (4) chemotherapy resistance, and (5) ability to recapitulate tumor heterogeneity in vivo

Sphere growth from 10 NSCLC patient samples and five lung cancer cell lines sorted for CD133+ expression

Sphere growth in 11 out of 15 lung adenocarcinoma malignant pleural effusion patient samples. Compared to adherent cells, sphere cells were associated with enhanced ALDH1 activity and Oct-4, Nanog, Notch3, and Stat3 mRNA expression

In the human lung cancer cell line H460, drug-selected cells (doxorubicin, cisplatin, or etoposide) demonstrated (1) spheroid formation; (2) self-renewal capacity and ability to differentiate; (3) expression of CD133; (4) enrichment for SP cells; (5) expression of embryonic stem cell markers, growth factor receptors, and chemokine receptors; and (6) high tumorigenic and metastatic potential

From patient lung cancer tissue samples, compared to CD133- cells, CD133+ cells displayed (1) enhanced expression of OCT4, (2) enhanced self-renewal ability, (3) increased expression of ABCG2, (4) enhanced resistance to chemotherapy and radiotherapy, (5) increased invasive ability, (6) increased in vivo tumor-restoration and proliferative capacity, and (7) increased spheroid formation From patient lung cancer tissue samples, compared to CD133- cells, CD133+ cells displayed (1) enhanced tumorigenic potential in vivo and (2) enhanced expression of ABCG2, CXCR4, $\alpha-6$ integrin (CD49f), OCT4, and NANOG. CD133+ cells demonstrated a self-renewal capacity in vitro, and cisplatin resistance in vitro and in vivo Expression of CD44 (62\% to $96 \%$ of tumor cells) in 6/10 human NSCLC lines examined. Compared to CD44- cells, CD44+ cells displayed (1) spheroid formation, (2) resistance to cisplatin treatment in vitro, (3) enhanced tumorigenicity in vivo, and (4) enhanced expression of stemness genes OCT4, NANOG, and SOX2

In human lung cancer cell lines (H460, H23, HTB-58, A549, H441, and H2170), compared to non-SP cells, SP cells demonstrated (1) enhanced invasiveness in vitro and tumorigenicity in vivo, (2) enhanced ABCG2 and human telomerase reverse transcriptase expression, and (3) resistance to multiple chemotherapy drugs

In human SCLC cells (NCI-H82, H146, and H526), SP expression comprised $<1 \%$ of cells. Compared to non-SP cells, SP cells were associated with (1) higher proliferative capacity; (2) efficient self-renewal capacity; (3) decreased expression of differentiated cell markers; (4) enhanced tumorigenicity; and (5) expression of genes associated with CICs, including ABCG2, MYC, SOX1/2, WNT1, and Notch and Hedgehog pathway genes

In human lung cancer cell lines ALDH1 activity was associated with (1) capacity for proliferation; (2) self-renewal and differentiation; (3) resistance to chemotherapy; (4) expression of CD133; and (5) enhanced tumorigenicity, as well as ability to recapitulate the original tumor heterogeneity in vivo

From 303 clinical patient specimens and controls, overexpression was positively correlated with stage and grade to tumor and associated with poorer prognosis for patients with early-stage lung cancer associated with CICs is resistance to cytotoxic agents. This resistance is attributed, in many cases, to increased expression of the ABCG2 multi-drug resistance transporter. ABCG2 is capable of pumping a variety of substrates, including cytotoxic drugs, out of the cell using ATPdependent mechanisms [25]. Expression of these transporters is responsible, in part, for the common clinical problem of multi-drug resistance [59] and may protect CICs from cytotoxic agents used for cancer treatment. To model the function of ABCG2 transporters, the DNA-intercalating dye Hoechst 33342 has been used [25]. The efflux of this dye allows the identification of a population of cells, known as the side population (SP) by flow cytometric analysis. Goodell et al. first described the SP for hematopoietic stem cells [60] and the SP has subsequently been used to study the hierarchical organization of blood and other tissues. This functional 
property has also been used to study putative CICs from a variety of human cancers, including acute myelogenous leukemia as well as gliomas and neuroblastomas [61-63]. More recently, SP cells have been the focus of research examining lung CICs. Ho et al. demonstrated in a study of six human lung cancer cell lines that cells in the SP exhibited properties of CICs including (1) enhanced invasiveness and tumorigenicity, (2) increased expression of human telomerase reverse transcriptase and ABCG2 expression, and (3) resistance to chemotherapy [15]. Salcido et al. showed, in a study examining SP in three human SCLC cell lines, that compared to nonSP cells, SP cells demonstrated (1) a higher proliferative capacity, with efficient self-renewal capacity and decreased expression of differentiated markers; (2) increased tumorigenicity; and (3) increased expression of self-renewal genes such as $S O X 1 / 2, W N T 1, M Y C$, and genes in the Notch and Hedgehog pathways [42].

Another functional marker of interest for isolating and characterizing CICs is aldehyde dehydrogenase-1 (ALDH1), a cellular detoxifying enzyme that oxidizes a variety of intracellular aldehydes to carboxylic acids [64]. The chemotherapeutics cisplatin and cyclophosphamide generate toxic aldehydes that are metabolized by ALDH1 [65]. High ALDH1 activity has been demonstrated in hematopoietic progenitor cells [66]. The activity of ALDH1 has also been detected in both normal and malignant human mammary stem cells and can be used to predict poor clinical outcomes in breast cancer [67]. Ginestier et al. demonstrated that high activity of ALDH1 identifies cells capable of self-renewal and high tumorigenicity in an immunocompromised mouse human tumor xenograft study [67]. In addition to hematopoietic and breast, activity of ALDH1 has subsequently been shown to enrich for normal stem cell populations or CICs in various other organ systems including brain, colon, and pancreas [68-70]. Recently, the activity and expression of ALDH1 has been correlated to the presence of lung CICs and the aggressiveness of lung tumors [16]. Jiang et al. has demonstrated using human NSCLC cell lines that cells expressing active ALDH1 are associated with a capacity for proliferation, self-renewal, and differentiation [16]. These cells also displayed expression of the CIC marker CD133, and CIC functional attributes of enhanced tumorigenicity and resistance to chemotherapy. In the same report, overexpression of ALDH1 was reported to correlate with poor prognosis for patients with early-stage NSCLC [16]. These findings make ALDH1 activity an attractive functional marker for identifying CICs, for use as a potential prognostic tool, and for use as a therapeutic target.

\section{Functional characteristics of lung CICs}

CICs from various cancers have been shown to form multicellular three-dimensional spheres, also termed "tumorspheres" or "spheroids" when grown in vitro in nonadherent, serum-free media conditions $[10,14,71]$. In these conditions, most cells undergo a form of apoptosis known as anoikis induced by anchorage-dependent cells detaching from the surrounding extracellular matrix. However, rare anoikisresistant cells divide and generate heterogeneous spheroid structures, composed of (1) cells that are differentiated and not anoikis-resistant, and (2) rare long-term proliferating anoikis-resistant cells - putative CICs. Sphere assays, and a recent mathematical interpretation of the sphere assay, allow for the assessment of the symmetric division expansion rate of malignant stem cell-like cells, and the evaluation of the effects of therapeutics on the self-renewal and proliferative activity of these cells [72]. Sphere assays are therefore powerful tools to assess the functional and phenotypic properties associated with putative CIC populations. Eramo et al., in a study of patient tumor samples, demonstrated sphere formation in seven out of 19 lung cancers [14]. In this study, long-term sphere culture was used to expand CICs for further analysis. Spherederived cells were found to have in vitro and in vivo properties of lung CICs including (1) self-renewal potential, (2) extensive proliferation and differentiation capacity, (3) expression of CD133, (4) expression of embryonic stemness genes such as OCT4 and NANOG, and (5) chemotherapy resistance and tumorigenicity. Mancini et al. have demonstrated sphere growth in 11 out of 15 lung adenocarcinoma malignant pleural effusion patient samples [19]. Compared to matched adherent cells, sphere-derived cells demonstrated enhanced ALDH1 activity and expression of mRNA for Nanog, Notch3, Oct-4, and STAT3. Despite the lack of sphere-forming capability for all tumors evaluated in these studies, the in vitro sphere assay is useful for characterizing and isolating CICs. Spheroid culture and demonstration of long-term self-renewal as spheres is a routine trait characterized for putative lung CIC populations in a number of additional studies $[12,13,17,18]$.

Chemoresistance and radiation resistance are another functional characteristic associated with CICs. Chemoresistance often goes hand in hand with expression of functional markers such as SP expression, but warrants inclusion on its own merit. Chemotherapy resistance and expression of the $\mathrm{SP} / \mathrm{ABCG} 2$ transporter has been used to enrich and characterize CICs. Levina et al. characterized drug-selected H460 human lung cancer cells and showed that these cells have characteristics of lung CICs including (1) sphere formation and self-renewal capacity; (2) an undifferentiated phenotype with an ability to differentiate; (3) expression of the SP, CD133, embryonic stem cell markers, and growth factor and chemokines receptors; and (4) a high tumorigenic and metastatic potential [18]. A variety of other studies have also used chemoresistance as a functional characteristic for CIC identification [12-17]. Less is known about radiation resistance and lung CICs. The existence of a subpopulation of radiation-resistant tumor cells has long been proposed by 
radiobiologists [73]. Characteristics of CICs that are thought to play a role in radiation resistance include, among others, (1) their relatively quiescent nature, (2) their capacity to regenerate tumors from a small starting number of cells, (3) more active DNA strand break repair pathways, and (4) down-regulation of senescence pathway associated with increased telomerase activity [74-77]. Addressing the mechanisms that cells use to become the treatmentresistant cell population may allow for specifically targeting these cells and increase the effectiveness of treatment.

Demonstration of CIC phenotypic markers and functional characteristics in vitro is often validated in vivo by tumor initiation studies. For human cancer cell lines/clinical samples, this is assessed through tumor formation from a limiting dilution of cells in immunocompromised mice. As all cells cannot induce tumors, the expansion of the resulting tumors is suggested to be driven by CICs. However, investigating CICs using xenograft mouse models for human tumor initiation is not without problems. Different strains of immunocompromised mice exhibit differing levels and types of residual immune effector cells. This in turn may alter the efficiency of tumor cell engraftment, and therefore the frequency or subpopulation of putative CICs may differ depending on the strain of immunocompromised mouse used. For instance, the detection frequency of tumorigenic cells in a melanoma xenograft model has been shown to be increased with the use of the NOD-SCID $\gamma$ (NSG, NOD.Cg$\mathrm{Prkdc}^{\text {scid }} I l 2 \mathrm{rg}^{\mathrm{tm} 1 \mathrm{Wjl}} / \mathrm{SzJ}$ ) mouse compared to ordinary SCID mice that retain some natural killer cell activity, with single cell transplants capable of forming tumors in NSG mice [78]. Furthermore, the immunocompromised mouse microenvironment does not recapitulate the microenvironment in a human patient with naturally occurring cancer. While xenograft studies allow the identification of a sub-population of cells able to recapitulate a tumor in an immunocompromised mouse, they may not present an accurate picture of the characteristics of CICs. In order for a tumor to form in humans, potential CICs must interact with the immune system to prevent tumor recognition and elimination. This interaction is lost in immunocompromised xenografts. It has been suggested that studies investigating the ability of different subtypes of cells to grow in immunocompromised mice demonstrates selection for cells that can best adapt to growth in mouse tissue. Therefore, these studies might not be differentiating true tumorigenic CICs from non-CICs. Alternatively, immunocompetent syngeneic models allow for interactions of the recipient mouse host immune system, a situation that more closely models cancer in humans. Kelly et al. demonstrated that tumor growth was not necessarily driven exclusively by rare stem cell-like cells, when as few as 10 unsorted mouse lymphoma cells were reported to transplant disease in syngeneic recipient mice [79]. Recently, the tumorigenicity of lung CICs have been assessed in syngeneic mice to better model the interactions between the host immune system and CICs [80]. Syngeneic models allow the examination of CIC-derived cancer vaccines and immunotherapy, treatment that are unable to be assessed in immunocompromised animals. These caveats support the need for more rigorous testing of the cancer stem/initiating cell hypothesis, and the development of mouse models that either more closely recapitulates the human microenvironment for studying human cancer cells, or the use of syngeneic mouse models to test CICs from murine cancers.

\section{Targeting CICs}

Resistance to chemotherapy and radiotherapy is thought to be behind the regeneration of tumor following initially successful treatment [81]. Compared to non-CICs, CICs are likely slow dividing, more resistant to apoptosis, and have an increased ability for DNA repair, making them more resistant to traditional methods of cancer treatment (reviewed in $[74,81])$. This led to the hypothesis that therapies targeting differentiated cells, but sparing CICs, result in tumor relapse, while innovative treatments targeting CICs, but sparing differentiated cells, might lead to tumor eradication (Fig. 1b). Developing innovative treatments is an ambitious approach, as different CICs will likely respond with varying sensitivities to treatment. This is made more difficult by the lack of universal and specific markers for CICs. Pre-clinically, the sphere assay provides a model for assessing the treatment efficacy on the self-renewal and proliferative activity of CICs specifically that does not rely on identification of specific markers [72]. This could provide a model for the highthroughput assessment of various novel therapies targeting CICs. Treatments targeting CICs discussed here include (1) targeting pathways involved in self-renewal, (2) differentiation therapy, (3) antibody-directed and other targeted therapies for CICs, and (4) future directions for immunotherapy approaches to target CICs.

\section{Targeting CICs self-renewal pathways}

There is increasing interest in investigating the self-renewal pathways utilized by CICs as therapeutic targets and combining these targeted CIC therapies with conventional treatments. These pathways include Hh, Notch, and Wnt.

The use of cyclopamine, a steroid-like molecule, to inhibit the Hh signaling pathway has shown promise in inhibiting the growth of medulloblastoma, basal cell carcinoma, and rhabdomyosarcoma [82, 83], and may find use in other tumors that are associated with aberrant Hh signaling. In SCLC, which has primitive features of pulmonary neuroendocrine cells, tumor development is dependent on activation of Hh signaling. Hh signaling plays a role in the normal differentiation of pulmonary neuroendocrine precursor cells 
and in the development of SCLC [84]. Hh pathway blockade by cyclopamine has demonstrated growth arrest and increased apoptosis for SCLC [84]. Therefore, some lung cancers may be susceptible to antagonists of the Hh pathway. A semisynthetic derivative of cyclopamine, IPI-926, is currently undergoing clinical trials for various tumors [85].

Inhibition of Notch signaling can be accomplished at many different levels (reviewed in [86]) including, among others, the use of (1) receptor decoys that interfere with Notch/ligand interactions, (2) $\gamma$-secretase inhibitors to block Notch activation through proteolytic cleavage of the receptor by $\gamma$-secretase protein complex, and (3) antibodies that interfere with Notch signaling. In the case of lung cancer, inhibition of Notch signaling, in some NSCLC lines, has shown evidence of increasing apoptosis and decreasing tumor growth [87, 88], potentially through blocking the self-renewal efficiency of CICs. Haruki et al. demonstrated that a dominant-negative Notch-3 receptor, capable of inhibiting the Notch-3 pathway, was effective in reducing soft agar growth of human lung cancer lines and sensitized these lines to subsequent EGF receptor tyrosine kinase inhibition treatment [87]. Konishi et al. demonstrated that MRK-003, a gamma-secretase inhibitor, inhibited Notch-3 signaling and subsequently reduced growth and increased apoptosis of human lung cancer cell lines in vitro and in vivo using xenograft models [88]. Assessment of antibodies directed against Notch signaling is ongoing with results showing tumor inhibition and inhibition of cell fate decisions such as self-renewal in adult stem/progenitor cells [86].

The Wnt pathway can be inhibited through a variety of mechanisms. Targeting of $\beta$-catenin has received attention with retinoic acid (RA) [89] and tyrosine kinase inhibitors such as imatinib $[90,91]$ being shown to down-regulate $\beta$ catenin signaling. A monoclonal antibody directed against Wnt-1 has demonstrated an effect against a NSCLC cell line in vitro through inhibiting the $\mathrm{Wnt} / \beta$-catenin signaling pathway and induction of apoptosis [92]. This monoclonal antibody also suppressed tumor growth in vivo for both nonestablished tumors and already established tumors.

The effect these treatments may have on somatic stem cells and other normal cells has to be weighed against their treatment efficacy against CICs. Targeted therapy against self-renewal pathway signaling molecules used by CICs may hold promise as a treatment, but to determine which patients are likely to benefit from treatment molecular tests assessing the signaling pathways activated in an individual tumor needs to be explored. This may be possible on a routine clinical basis as the cost of whole tumor genome expression analysis continues to fall. Designing rational treatment regimens targeting signaling pathways needs to be incorporated into current treatments to most effectively ablate self-renewal capacity in CICs and induce apoptosis of these cells leading to reduction in tumor burden.
Targeting CICs using differentiation therapy

Another approach to target CICs is the induction of their differentiation, resulting in the loss of their ability for selfrenewal and tumor maintenance. RA is one therapy used in the clinic to promote differentiation of epithelial cells [82]. RA-based therapy followed by chemotherapy has been used in acute promyelocytic leukemia and could also find use in solid tumor therapy [93]. The TGF- $\beta$ superfamily member BMP-4 has been utilized to differentiate human glioblastoma stem cell-like CICs, with subsequent reduction in proliferation and induction of differentiation markers noted [94]. Recently, Azzi et al. demonstrated the use of interleukin (IL)-15 in the differentiation of renal CICs, resulting in the decrease of the CIC pool and generating differentiated non-tumorigenic cells that are susceptible to treatment with chemotherapy [95]. The use of IL-15 as a differentiation therapy is interesting in light of its other roles as an immuneregulating and anti-cancer cytokine [96]. Inducing differentiation in lung CICs may hold promise as a novel treatment approach.

Targeting CICs using antibody-directed and other targeted therapies

Antibody therapy directed specifically to CICs may find use in the clinic (Fig. 2a). The use of monoclonal antibodies (mAbs) targeting CICs is a relatively new approach. CICs are typically present in low frequency compared to nonCICs (typical estimates range between $0.1 \%$ and $10 \%$ of all tumor cells), and markers identifying CICs are not well characterized. Additionally, cell surface markers that have been characterized are not uniformly expressed by all CICs and often overlap with normal stem cells or non-tumorigenic cells. Identification of novel markers on CICs, preferably not expressed or with low expression on somatic stem cells or non-tumor cells, would be ideal. Additionally, therapy may be against the CIC itself (direct therapy) or against cells that maintain the CIC niche in the tumor (indirect therapy).

Direct $\mathrm{mAb}$ therapy specifically targeting lung CICs has not been well studied. However, two of the markers expressed by putative lung CICs, CD133 and CD44, do have the potential to be targeted through $\mathrm{mAb}$ therapy. $\mathrm{AC} 133$ is a mAb that recognizes CD133. In a pre-clinical study, AC133 conjugated to a cytotoxic drug was used to target hepatocellular cancer cells in vitro and in vivo with demonstration of tumor growth inhibition [97]. Similarly, an antibody directed against CD44, H90, has demonstrated efficacy in an AML model by specifically targeting CICs leading to promotion of differentiation, and inhibition of tumor proliferation and niche localization [98]. CD44 is a molecule with multiple variants, and future characterization of these variants is necessary for production of ideal mAbs 


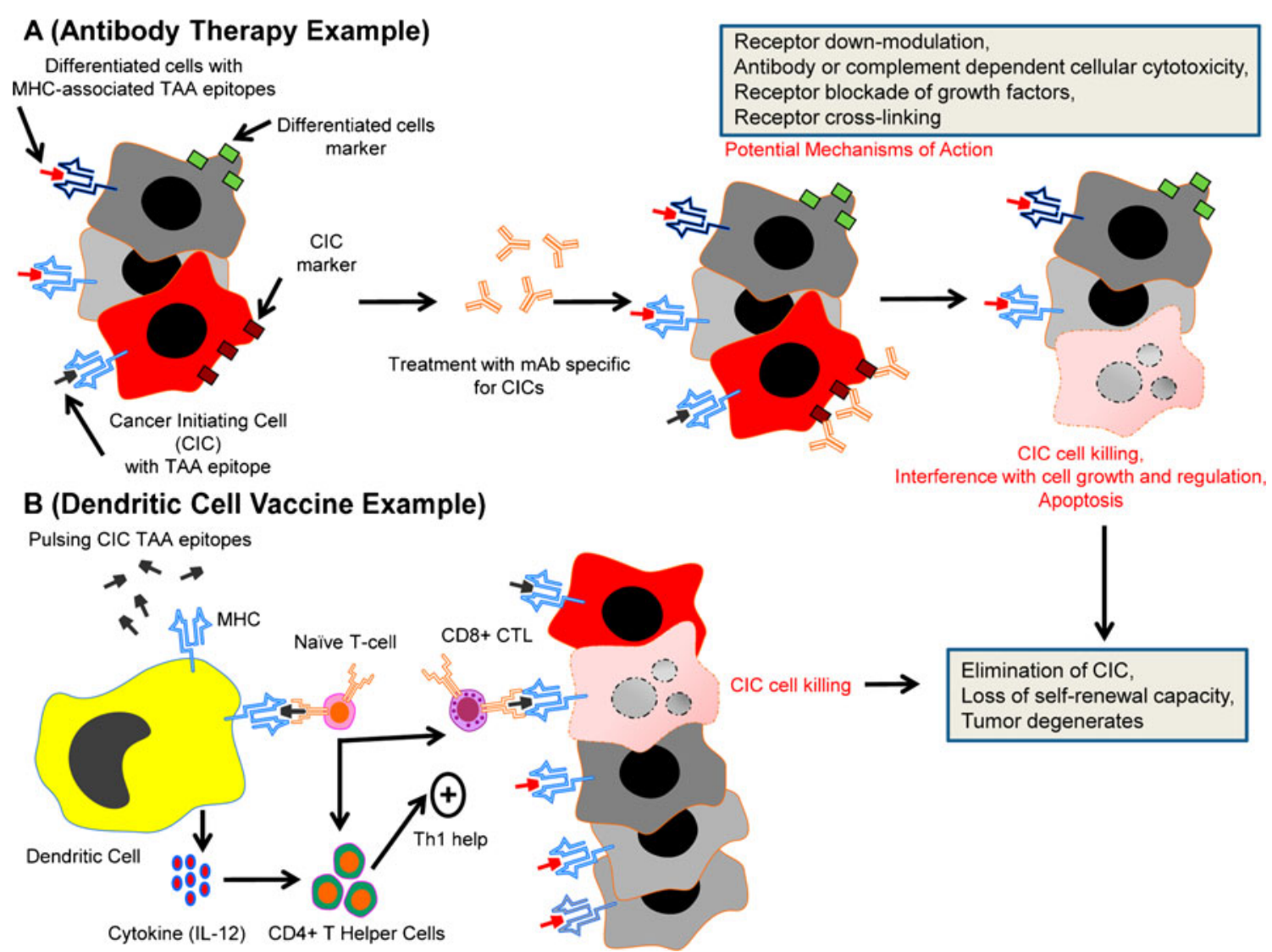

Fig. 2 Targeted therapy for CICs. a CICs are likely to express specific markers (cell surface antigens in the example shown) that can be used for targeted therapy. One approach will be treatment with monoclonal antibodies $(\mathrm{mAb})$ specific for markers expressed on CICs but not on differentiated cells. Through a variety of mechanisms, mAb therapy can lead to interference in cell growth or regulation of CICs or can induce apoptosis or cell killing directly. b Further characterization of lung CICs will likely reveal expressed antigens that can be used to target them. One cancer vaccine approach to eliminate CICs is shown here using antigen-presenting dendritic cells (DCs) pulsed with tumor- associated antigen (TAA) epitopes specific for CICs. DCs process and present TAA on major histocompatibility complexes (MHC) to T cells to stimulate a CD8+ cytotoxic T-lymphocyte (CTL) response that is thought to be critical for tumor elimination. DCs also express all of the necessary cytokine and co-stimulatory molecules, such as IL-12, to further direct the immune response to tumor and induce CD4+ Th1 Thelper cells. Once CICs are eliminated from the tumor the capacity for self-renewal is lost and the tumor degenerates. Note that tumor debulking of differentiated cells will also need to be accomplished concurrently for specific tumor types. Development of strategies to specifically target CD44/hyaluronan axis is ongoing (reviewed in [99]).

Stem cell niches are locations in a tissue that specifically support somatic stem cells and allow the repopulation of the stem cell compartment from stem cells or differentiated cells if the stem cell compartment is depleted [20]. Similarly, a tumor CIC niche specifically supports CICs. Therefore, it is possible that therapy that disrupts the tumor CIC niche could lead to the subsequent eradiation of CICs. Alternatively, tumor therapy that depletes CICs, but does not eradicate the tumor CIC niche, could lead to repopulation of the CIC pool.

Vascular endothelial cells are a component of the neural stem cell niche [100], and inhibitors of vascular endothelial growth factor (VEGF) have shown promise in ablating $\mathrm{CICs}$, in addition to decreasing tumor vascularization, in a xenograft model of glioblastoma [101]. Anti-vasculature therapies include anti-VEGF antibodies (bevacizumab), anti-EGFR antibodies (cetuximab), and small molecules such as erlotinib that act on EGFR. CICs have been reported to express higher amounts of VEGF in both normoxic and hypoxic conditions compared to non-CICs. In a glioma model, high VEGF expression has been shown to lead to increased endothelial cell migration and tube formation, both of which can be subsequently blocked with bevacizumab [102].

Cells bearing the CXCR4 receptor molecule are capable of homing to specific niche environments via responding to a signal gradient of stromal cell-derived factor-1 (SDF-1/ CXCL12). CXCR4 has been demonstrated to play a role in metastatic and drug-resistant lung CICs [103, 104] and is up-regulated in drug-selected lung CICs [18]. Thus, antagonists of the CXCR4/CXCL12 axis, such as Plerixafor 
(AMD3100) and T140 analogs (TN14003/BKT140), are of therapeutic interest for blocking metastatic disease, sensitizing tumor cells to chemotherapy, and targeting lung CICs [105].

Several $\mathrm{mAbs}$ have been utilized that neutralize autocrine signaling mediators involved in CIC growth and resistance to chemotherapy. In a preclinical model, an anti-IL-3 receptor alpha chain (CD123) neutralizing antibody demonstrated impairment of homing of leukemic CICs to the bone marrow, and a reduction in AML burden for mice with preestablished disease [106]. In a solid tumor model, an antiIL-4 neutralizing antibody has been characterized for the ability to impair CICs in colorectal cancer [107, 108]. Todaro et al. demonstrated that CD133+ colon CICs utilize IL-4 to protect themselves from apoptosis, and that an antiIL-4 neutralizing antibody will selectively sensitize these CICs to subsequent chemotherapy, thereby enhancing antitumor efficacy [107].

CICs are similar to normal somatic stem cells in many regards, meaning some treatments aimed at targeting CICs might put somatic stem cells at risk. $\mathrm{ABC}$ transporter (SP cells) inhibitors used in combination with chemotherapy have been shown to increase the efficacy of chemotherapy targeting CICs [81]. Also, an anti-ABCB5 antibody has been used to treat melanoma in a xenograft model resulting in reduction in tumor size and tumor eradication in $70 \%$ of treated animals [109]. The proposed mechanism for this action was antibody-dependent cellular cytotoxicity (ADCC) directed against CICs. However, treatments targeting ABC transporters could also affect somatic stem cells, leading to potential toxicity in the bone marrow and improper maintenance of the blood-brain barrier [110].

Additional approaches exist to target CICs and these new strategies are the focus of ongoing research. Histone deacetylase inhibitors and other epigenetic-acting drugs are potentially useful for targeting CICs [111], as are small molecule inhibitors targeting key proteins in the intrinsic apoptotic pathway, a pathway often altered in CICs [112, 113]. Similarly, the knock-down of the "stemness" transcription factor Oct-4 has been shown to lead to apoptosis in CIC-like cells in a murine model of lung cancer [114].

Targeting CICs using immunotherapy

Immunotherapy strategies utilize the patient's own immune system in the treatment of cancer by inducing or enhancing (activation immunotherapies) immune responses to tumor or by suppressing (suppression immunotherapies) immune responses that are blocking effective tumor targeting. One promising activation immunotherapy strategy is the use of dendritic cell (DC) vaccines. DCs are powerful antigenpresenting cells that play a central role in initiating and directing immune responses through the processing of antigens and presentation of epitopes in the context of surface MHC molecules to T cells. DCs are equipped with all of the necessary co-stimulatory and cytokine signals to stimulate cytolytic T-lymphocyte (CTL) responses to tumorassociated antigens (TAA), leading to the elimination of tumors expressing these antigens (Fig. 2b). Cancer vaccines targeting solid tumors have been employed, with varying success, both pre-clinically and clinically in the treatment of cancer [115]. Several clinical trials have examined the efficacy of epitope-modified DCs, often accomplished by "pulsing" DCs ex vivo with synthetic TAA peptides [116, 117]. One drawback of peptide loading is the need for knowledge of the antigen sequence and the requirement for favorable binding affinity of the peptide for MHC. An alternative strategy is to load DCs with protein lysates generated from tumors. Tumor lysates, however, contain many antigens, most of which are not tumor specific.

Vaccine approaches that specifically target CIC antigens, and therefore CICs, may be more successful [118]. In a preclinical trial using irradiated CICs as antigens for a DC vaccine for glioblastoma, activation of antigen specific $\mathrm{T}$ cells and $\gamma$-interferon production was seen in the vaccinated animals [119]. These immune responses were correlated with prolonged survival in animals bearing tumor compared to an equivalent vaccine derived from non-CICs. In another pre-clinical study targeting murine CT26 colon cancer, Mori et al. compared vaccination against TAA expressed by CIC versus those expressed by non-CIC. Vaccination against non-CIC antigens did not induce an anti-tumor response whereas vaccination against antigens expressed on CIC led to a significant antitumor response [120]. These results highlight the importance of targeting antigens on CICs for an effective vaccine strategy.

\section{Concluding remarks}

Investigating CICs are not without potential difficulties, including among others, (1) defining CICs and their markers, (2) the use xenotransplantation models, (3) identifying and measuring CIC stemness, and (4) the challenge of developing therapies that specifically target CICs (for a review of these see [121]). Studying lung CIC may have a major impact on cancer treatment by suggesting novel therapeutic approaches; however, additional studies are still required to further characterize the plasticity, heterogeneity, immune-modulating properties, and functional/physical phenotype of lung CICs. These studies will aid in identifying therapies that can specifically target lung CICs. Prospective clinical investigations assessing putative lung CIC markers and functional characteristics should be performed, with a focus on assessing cells with these characteristics before, during, and after treatment. In addition to suggesting 
new targets for therapy, these studies may provide diagnostic and prognostic information. Targeted therapy against CICs may need to be personalized for each patient, either through assessing the appropriate $\mathrm{mAb}$ or differentiation therapy required for their particular CIC phenotype, or through application of immunotherapy. To be effective, new therapies targeting CICs will need to be incorporated into clinical practice alongside traditional therapies that debulk the tumor and therapies that aim to interfere with the supportive niche of CICs, including anti-angiogenic or anti-stroma therapy. In this setting, the development of targeted CIC therapies could lead to meaningful increases in clinical responses.

Conflict of interest The authors have no conflict of interest to report with respect to this work.

Open Access This article is distributed under the terms of the Creative Commons Attribution License which permits any use, distribution, and reproduction in any medium, provided the original author(s) and the source are credited.

\section{References}

1. Ferlay J, Shin HR, Bray F, Forman D, Mathers C, Parkin DM (2010) Estimates of worldwide burden of cancer in 2008: GLOBOCAN 2008. Int J Cancer 127(12):2893-2917

2. Collins LG, Haines C, Perkel R, Enck RE (2007) Lung cancer: diagnosis and management. Am Fam Physician 75(1):56-63

3. Parker SL, Tong T, Bolden S, Wingo PA (1997) Cancer statistics, 1997. CA Cancer J Clin 47(1):5-27

4. Turrisi AT, Sherman CA (2002) The treatment of limited small cell lung cancer: a report of the progress made and future prospects. Eur J Cancer 38(2):279-291

5. Gottesman MM (2002) Mechanisms of cancer drug resistance. Annu Rev Med 53:615-627

6. Donnenberg VS, Donnenberg AD (2005) Multiple drug resistance in cancer revisited: the cancer stem cell hypothesis. J Clin Pharmacol 45(8):872-877

7. Bonnet D, Dick JE (1997) Human acute myeloid leukemia is organized as a hierarchy that originates from a primitive hematopoietic cell. Nat Med 3(7):730-737

8. Lapidot T, Sirard C, Vormoor J, Murdoch B, Hoang T, CaceresCortes J, Minden M, Paterson B, Caligiuri MA, Dick JE (1994) A cell initiating human acute myeloid leukaemia after transplantation into SCID mice. Nature 367(6464):645-648

9. Galli R, Binda E, Orfanelli U, Cipelletti B, Gritti A, De Vitis S, Fiocco R, Foroni C, Dimeco F, Vescovi A (2004) Isolation and characterization of tumorigenic, stem-like neural precursors from human glioblastoma. Cancer Res 64(19):7011-7021

10. Singh SK, Hawkins C, Clarke ID, Squire JA, Bayani J, Hide T, Henkelman RM, Cusimano MD, Dirks PB (2004) Identification of human brain tumour initiating cells. Nature 432(7015):396-401

11. Al-Hajj M, Wicha MS, Benito-Hernandez A, Morrison SJ, Clarke MF (2003) Prospective identification of tumorigenic breast cancer cells. Proc Natl Acad Sci U S A 100(7):3983-3988

12. Bertolini G, Roz L, Perego P, Tortoreto M, Fontanella E, Gatti L, Pratesi G, Fabbri A, Andriani F, Tinelli S, Roz E, Caserini R, Lo
Vullo S, Camerini T, Mariani L, Delia D, Calabro E, Pastorino U, Sozzi G (2009) Highly tumorigenic lung cancer CD133+ cells display stem-like features and are spared by cisplatin treatment. Proc Natl Acad Sci U S A 106(38):16281-16286

13. Chen YC, Hsu HS, Chen YW, Tsai TH, How CK, Wang CY, Hung SC, Chang YL, Tsai ML, Lee YY, Ku HH, Chiou SH (2008) Oct-4 expression maintained cancer stem-like properties in lung cancerderived CD133-positive cells. PLoS One 3(7):e2637

14. Eramo A, Lotti F, Sette G, Pilozzi E, Biffoni M, Di Virgilio A, Conticello C, Ruco L, Peschle C, De Maria R (2008) Identification and expansion of the tumorigenic lung cancer stem cell population. Cell Death Differ 15(3):504-514

15. Ho MM, Ng AV, Lam S, Hung JY (2007) Side population in human lung cancer cell lines and tumors is enriched with stemlike cancer cells. Cancer Res 67(10):4827-4833

16. Jiang F, Qiu Q, Khanna A, Todd NW, Deepak J, Xing L, Wang H, Liu Z, Su Y, Stass SA, Katz RL (2009) Aldehyde dehydrogenase 1 is a tumor stem cell-associated marker in lung cancer. Mol Cancer Res 7(3):330-338

17. Leung EL, Fiscus RR, Tung JW, Tin VP, Cheng LC, Sihoe AD, Fink LM, Ma Y, Wong MP (2010) Non-small cell lung cancer cells expressing CD44 are enriched for stem cell-like properties. PLoS One 5(11):e14062

18. Levina V, Marrangoni AM, DeMarco R, Gorelik E, Lokshin AE (2008) Drug-selected human lung cancer stem cells: cytokine network, tumorigenic and metastatic properties. PLoS One 3(8):e3077

19. Mancini R, Giarnieri E, De Vitis C, Malanga D, Roscilli G, Noto A, Marra E, Laudanna C, Zoppoli P, De Luca P, Affuso A, Ruco L, Di Napoli A, Mesiti G, Aurisicchio L, Ricci A, Mariotta S, Pisani L, Andreetti C, Viglietto G, Rendina EA, Giovagnoli MR, Ciliberto G (2011) Spheres derived from lung adenocarcinoma pleural effusions: molecular characterization and tumor engraftment. PLoS One 6(7):e21320

20. Potten CS, Loeffler M (1990) Stem cells: attributes, cycles, spirals, pitfalls and uncertainties. Lessons for and from the crypt. Development 110(4):1001-1020

21. Snippert HJ, van der Flier LG, Sato T, van Es JH, van den Born M, Kroon-Veenboer C, Barker N, Klein AM, van Rheenen J, Simons BD, Clevers H (2010) Intestinal crypt homeostasis results from neutral competition between symmetrically dividing Lgr5 stem cells. Cell 143(1):134-144

22. Lander AD (2011) The individuality of stem cells. BMC Biol 9:40

23. Sullivan JP, Minna JD, Shay JW (2010) Evidence for selfrenewing lung cancer stem cells and their implications in tumor initiation, progression, and targeted therapy. Cancer Metastasis Rev 29(1):61-72

24. Hiyama E, Hiyama K (2007) Telomere and telomerase in stem cells. Br J Cancer 96(7):1020-1024

25. Zhou S, Schuetz JD, Bunting KD, Colapietro AM, Sampath J, Morris JJ, Lagutina I, Grosveld GC, Osawa M, Nakauchi H, Sorrentino BP (2001) The ABC transporter Bcrp1/ABCG2 is expressed in a wide variety of stem cells and is a molecular determinant of the side-population phenotype. Nat Med 7 (9):1028-1034

26. Brabletz T, Jung A, Spaderna S, Hlubek F, Kirchner T (2005) Opinion: migrating cancer stem cells - an integrated concept of malignant tumour progression. Nat Rev Cancer 5(9):744-749

27. Bjerkvig R, Tysnes BB, Aboody KS, Najbauer J, Terzis AJ (2005) Opinion: the origin of the cancer stem cell: current controversies and new insights. Nat Rev Cancer 5(11):899-904

28. Pepicelli CV, Lewis PM, McMahon AP (1998) Sonic hedgehog regulates branching morphogenesis in the mammalian lung. Curr Biol 8(19):1083-1086

29. Bhardwaj G, Murdoch B, Wu D, Baker DP, Williams KP, Chadwick K, Ling LE, Karanu FN, Bhatia M (2001) Sonic hedgehog induces 
the proliferation of primitive human hematopoietic cells via BMP regulation. Nat Immunol 2(2):172-180

30. Peacock CD, Wang Q, Gesell GS, Corcoran-Schwartz IM, Jones E, Kim J, Devereux WL, Rhodes JT, Huff CA, Beachy PA, Watkins DN, Matsui W (2007) Hedgehog signaling maintains a tumor stem cell compartment in multiple myeloma. Proc Natl Acad Sci U S A 104(10):4048-4053

31. Rubin LL, de Sauvage FJ (2006) Targeting the Hedgehog pathway in cancer. Nat Rev Drug Discov 5(12):1026-1033

32. Gaiano N, Fishell G (2002) The role of notch in promoting glial and neural stem cell fates. Annu Rev Neurosci 25:471-490

33. Karanu FN, Murdoch B, Gallacher L, Wu DM, Koremoto M, Sakano S, Bhatia M (2000) The notch ligand jagged-1 represents a novel growth factor of human hematopoietic stem cells. J Exp Med 192(9):1365-1372

34. Radtke F, Raj K (2003) The role of Notch in tumorigenesis: oncogene or tumour suppressor? Nat Rev Cancer 3(10):756-767

35. Dang TP, Eichenberger S, Gonzalez A, Olson S, Carbone DP (2003) Constitutive activation of Notch3 inhibits terminal epithelial differentiation in lungs of transgenic mice. Oncogene 22 (13): 1988-1997

36. Tsao PN, Chen F, Izvolsky KI, Walker J, Kukuruzinska MA, Lu J, Cardoso WV (2008) Gamma-secretase activation of notch signaling regulates the balance of proximal and distal fates in progenitor cells of the developing lung. J Biol Chem 283 (43):29532-29544

37. Clevers H (2006) Wnt/beta-catenin signaling in development and disease. Cell 127(3):469-480

38. Gat U, DasGupta R, Degenstein L, Fuchs E (1998) De Novo hair follicle morphogenesis and hair tumors in mice expressing a truncated beta-catenin in skin. Cell 95(5):605-614

39. Polakis P (2000) Wnt signaling and cancer. Genes Dev 14 (15): $1837-1851$

40. Uematsu K, He B, You L, Xu Z, McCormick F, Jablons DM (2003) Activation of the Wnt pathway in non small cell lung cancer: evidence of dishevelled overexpression. Oncogene 22(46):7218-7221

41. Takahashi K, Yamanaka S (2006) Induction of pluripotent stem cells from mouse embryonic and adult fibroblast cultures by defined factors. Cell 126(4):663-676

42. Salcido CD, Larochelle A, Taylor BJ, Dunbar CE, Varticovski L (2010) Molecular characterisation of side population cells with cancer stem cell-like characteristics in small-cell lung cancer. Br J Cancer 102(11):1636-1644

43. Yin AH, Miraglia S, Zanjani ED, Almeida-Porada G, Ogawa M, Leary AG, Olweus J, Kearney J, Buck DW (1997) AC133, a novel marker for human hematopoietic stem and progenitor cells. Blood 90(12):5002-5012

44. Miraglia S, Godfrey W, Yin AH, Atkins K, Warnke R, Holden JT, Bray RA, Waller EK, Buck DW (1997) A novel fivetransmembrane hematopoietic stem cell antigen: isolation, characterization, and molecular cloning. Blood 90(12):5013-5021

45. Uchida N, Buck DW, He D, Reitsma MJ, Masek M, Phan TV, Tsukamoto AS, Gage FH, Weissman IL (2000) Direct isolation of human central nervous system stem cells. Proc Natl Acad Sci U S A 97(26):14720-14725

46. Corbeil D, Roper K, Hellwig A, Tavian M, Miraglia S, Watt SM, Simmons PJ, Peault B, Buck DW, Huttner WB (2000) The human AC133 hematopoietic stem cell antigen is also expressed in epithelial cells and targeted to plasma membrane protrusions. $\mathrm{J}$ Biol Chem 275(8):5512-5520

47. Salven P, Mustjoki S, Alitalo R, Alitalo K, Rafii S (2003) VEGFR-3 and CD133 identify a population of CD34+ lymphatic/vascular endothelial precursor cells. Blood 101(1):168-172

48. Collins AT, Berry PA, Hyde C, Stower MJ, Maitland NJ (2005) Prospective identification of tumorigenic prostate cancer stem cells. Cancer Res 65(23):10946-10951
49. O'Brien CA, Pollett A, Gallinger S, Dick JE (2007) A human colon cancer cell capable of initiating tumour growth in immunodeficient mice. Nature 445(7123):106-110

50. Ricci-Vitiani L, Lombardi DG, Pilozzi E, Biffoni M, Todaro M, Peschle C, De Maria R (2007) Identification and expansion of human colon-cancer-initiating cells. Nature 445(7123):111-115

51. Yin S, Li J, Hu C, Chen X, Yao M, Yan M, Jiang G, Ge C, Xie H, Wan D, Yang S, Zheng S, Gu J (2007) CD133 positive hepatocellular carcinoma cells possess high capacity for tumorigenicity. Int J Cancer 120(7):1444-1450

52. Wu Y, Wu PY (2009) CD133 as a marker for cancer stem cells: progresses and concerns. Stem Cells Dev 18(8):1127-1134

53. Meng X, Li M, Wang X, Wang Y, Ma D (2009) Both CD133+ and CD133- subpopulations of A549 and H446 cells contain cancer-initiating cells. Cancer Sci 100(6):1040-1046

54. Miletti-Gonzalez KE, Chen S, Muthukumaran N, Saglimbeni GN, Wu X, Yang J, Apolito K, Shih WJ, Hait WN, RodriguezRodriguez L (2005) The CD44 receptor interacts with Pglycoprotein to promote cell migration and invasion in cancer. Cancer Res 65(15):6660-6667. doi:10.1158/0008-5472.can-043478

55. Bankfalvi A, Terpe HJ, Breukelmann D, Bier B, Rempe D, Pschadka G, Krech R, Bocker W (1998) Gains and losses of CD44 expression during breast carcinogenesis and tumour progression. Histopathology 33(2):107-116

56. Shipitsin M, Campbell LL, Argani P, Weremowicz S, BloushtainQimron N, Yao J, Nikolskaya T, Serebryiskaya T, Beroukhim R, $\mathrm{Hu}$ M, Halushka MK, Sukumar S, Parker LM, Anderson KS, Harris LN, Garber JE, Richardson AL, Schnitt SJ, Nikolsky Y, Gelman RS, Polyak K (2007) Molecular definition of breast tumor heterogeneity. Cancer Cell 11(3):259-273

57. Bourguignon LY, Gilad E, Peyrollier K (2007) Heregulinmediated ErbB2-ERK signaling activates hyaluronan synthases leading to CD44-dependent ovarian tumor cell growth and migration. J Biol Chem 282(27):19426-19441

58. Toole BP, Slomiany MG (2008) Hyaluronan, CD44 and Emmprin: partners in cancer cell chemoresistance. Drug Resist Updat 11 (3): $110-121$

59. Sarkadi B, Ozvegy-Laczka C, Nemet K, Varadi A (2004) ABCG2 - a transporter for all seasons. FEBS Lett 567(1):116-120

60. Goodell MA, Brose K, Paradis G, Conner AS, Mulligan RC (1996) Isolation and functional properties of murine hematopoietic stem cells that are replicating in vivo. J Exp Med 183 (4):1797-1806

61. Wulf GG, Wang RY, Kuehnle I, Weidner D, Marini F, Brenner MK, Andreeff M, Goodell MA (2001) A leukemic stem cell with intrinsic drug efflux capacity in acute myeloid leukemia. Blood 98(4):1166-1173

62. Hirschmann-Jax C, Foster AE, Wulf GG, Nuchtern JG, Jax TW, Gobel U, Goodell MA, Brenner MK (2004) A distinct "side population" of cells with high drug efflux capacity in human tumor cells. Proc Natl Acad Sci U S A 101(39):14228-14233

63. Kondo T, Setoguchi T, Taga T (2004) Persistence of a small subpopulation of cancer stem-like cells in the C6 glioma cell line. Proc Natl Acad Sci U S A 101(3):781-786

64. Russo JE, Hilton J (1988) Characterization of cytosolic aldehyde dehydrogenase from cyclophosphamide resistant L1210 cells. Cancer Res 48(11):2963-2968

65. Douville J, Beaulieu R, Balicki D (2009) ALDH1 as a functional marker of cancer stem and progenitor cells. Stem Cells Dev 18 (1): $17-25$

66. Kastan MB, Schlaffer E, Russo JE, Colvin OM, Civin CI, Hilton J (1990) Direct demonstration of elevated aldehyde dehydrogenase in human hematopoietic progenitor cells. Blood 75(10):1947-1950

67. Ginestier C, Hur MH, Charafe-Jauffret E, Monville F, Dutcher J, Brown M, Jacquemier J, Viens P, Kleer CG, Liu S, Schott A, 
Hayes D, Birnbaum D, Wicha MS, Dontu G (2007) ALDH1 is a marker of normal and malignant human mammary stem cells and a predictor of poor clinical outcome. Cell Stem Cell 1(5):555-567

68. Corti S, Locatelli F, Papadimitriou D, Donadoni C, Salani S, Del Bo R, Strazzer S, Bresolin N, Comi GP (2006) Identification of a primitive brain-derived neural stem cell population based on aldehyde dehydrogenase activity. Stem Cells 24(4):975-985

69. Huang EH, Hynes MJ, Zhang T, Ginestier C, Dontu G, Appelman H, Fields JZ, Wicha MS, Boman BM (2009) Aldehyde dehydrogenase 1 is a marker for normal and malignant human colonic stem cells (SC) and tracks SC overpopulation during colon tumorigenesis. Cancer Res 69(8):3382-3389

70. Kim MP, Fleming JB, Wang H, Abbruzzese JL, Choi W, Kopetz S, McConkey DJ, Evans DB, Gallick GE (2011) ALDH activity selectively defines an enhanced tumor-initiating cell population relative to CD133 expression in human pancreatic adenocarcinoma. PLoS One 6(6):e20636

71. Ponti D, Costa A, Zaffaroni N, Pratesi G, Petrangolini G, Coradini D, Pilotti S, Pierotti MA, Daidone MG (2005) Isolation and in vitro propagation of tumorigenic breast cancer cells with stem/progenitor cell properties. Cancer Res 65(13):5506-5511

72. Deleyrolle LP, Ericksson G, Morrison BJ, Lopez JA, Burrage K, Burrage P, Vescovi A, Rietze RL, Reynolds BA (2011) Determination of somatic and cancer stem cell self-renewing symmetric division rate using sphere assays. PLoS One 6(1):e15844

73. Withers HR, Taylor JM, Maciejewski B (1988) The hazard of accelerated tumor clonogen repopulation during radiotherapy. Acta Oncol 27(2):131-146

74. Al-Ejeh F, Smart CE, Morrison BJ, Chenevix-Trench G, Lopez JA, Lakhani SR, Brown MP, Khanna KK (2011) Breast cancer stem cells: treatment resistance and therapeutic opportunities. Carcinogenesis 32(5):650-658

75. Rich JN (2007) Cancer stem cells in radiation resistance. Cancer Res 67(19):8980-8984

76. Phillips TM, McBride WH, Pajonk F (2006) The response of CD24(-/low)/CD44+ breast cancer-initiating cells to radiation. J Natl Cancer Inst 98(24):1777-1785

77. Karimi-Busheri F, Rasouli-Nia A, Mackey JR, Weinfeld M (2010) Senescence evasion by MCF-7 human breast tumorinitiating cells. Breast Cancer Res 12(3):R31

78. Quintana E, Shackleton M, Sabel MS, Fullen DR, Johnson TM, Morrison SJ (2008) Efficient tumour formation by single human melanoma cells. Nature 456(7222):593-598

79. Kelly PN, Dakic A, Adams JM, Nutt SL, Strasser A (2007) Tumor growth need not be driven by rare cancer stem cells. Science 317(5836):337

80. Morrison BJ, Steel JC, Morris JC (2012) Sphere culture of murine lung cancer cell lines are enriched with cancer initiating cells. PLoS One 7(11):e49752

81. Dean M, Fojo T, Bates S (2005) Tumour stem cells and drug resistance. Nat Rev Cancer 5(4):275-284

82. Massard C, Deutsch E, Soria JC (2006) Tumour stem celltargeted treatment: elimination or differentiation. Ann Oncol 17 (11):1620-1624

83. Taipale J, Chen JK, Cooper MK, Wang B, Mann RK, Milenkovic L, Scott MP, Beachy PA (2000) Effects of oncogenic mutations in Smoothened and Patched can be reversed by cyclopamine. Nature 406(6799): 1005-1009

84. Watkins DN, Berman DM, Burkholder SG, Wang B, Beachy PA, Baylin SB (2003) Hedgehog signalling within airway epithelial progenitors and in small-cell lung cancer. Nature 422(6929):313317

85. Tremblay MR, Lescarbeau A, Grogan MJ, Tan E, Lin G, Austad BC, Yu LC, Behnke ML, Nair SJ, Hagel M, White K, Conley J, Manna JD, Alvarez-Diez TM, Hoyt J, Woodward CN, Sydor JR, Pink M, MacDougall J, Campbell MJ, Cushing J, Ferguson J,
Curtis MS, McGovern K, Read MA, Palombella VJ, Adams J, Castro AC (2009) Discovery of a potent and orally active hedgehog pathway antagonist (IPI-926). J Med Chem 52(14):4400 4418

86. Rizzo P, Osipo C, Foreman K, Golde T, Osborne B, Miele L (2008) Rational targeting of Notch signaling in cancer. Oncogene 27(38):5124-5131

87. Haruki N, Kawaguchi KS, Eichenberger S, Massion PP, Olson S, Gonzalez A, Carbone DP, Dang TP (2005) Dominant-negative Notch3 receptor inhibits mitogen-activated protein kinase pathway and the growth of human lung cancers. Cancer Res 65 (9):3555-3561

88. Konishi J, Kawaguchi KS, Vo H, Haruki N, Gonzalez A, Carbone DP, Dang TP (2007) Gamma-secretase inhibitor prevents Notch3 activation and reduces proliferation in human lung cancers. Cancer Res 67(17):8051-8057

89. Luu HH, Zhang R, Haydon RC, Rayburn E, Kang Q, Si W, Park JK, Wang H, Peng Y, Jiang W, He TC (2004) Wnt/beta-catenin signaling pathway as a novel cancer drug target. Curr Cancer Drug Targets 4(8):653-671

90. Haydon RC, Zhou L, He TC (2004) Tyrosine kinase inhibitor STI-571: the new wonder drug of cancer therapy. Cancer Biol Ther 3(4):393-394

91. Zhou L, An N, Haydon RC, Zhou Q, Cheng H, Peng Y, Jiang W, Luu HH, Vanichakarn P, Szatkowski JP, Park JY, Breyer B, He TC (2003) Tyrosine kinase inhibitor STI-571/Gleevec downregulates the beta-catenin signaling activity. Cancer Lett 193 (2):161-170

92. He B, You L, Uematsu K, Xu Z, Lee AY, Matsangou M, McCormick F, Jablons DM (2004) A monoclonal antibody against Wnt-1 induces apoptosis in human cancer cells. Neoplasia 6(1):7-14

93. Ohno R, Asou N, Ohnishi K (2003) Treatment of acute promyelocytic leukemia: strategy toward further increase of cure rate. Leukemia 17(8):1454-1463

94. Piccirillo SG, Reynolds BA, Zanetti N, Lamorte G, Binda E, Broggi G, Brem H, Olivi A, Dimeco F, Vescovi AL (2006) Bone morphogenetic proteins inhibit the tumorigenic potential of human brain tumour-initiating cells. Nature 444(7120):761-765

95. Azzi S, Bruno S, Giron-Michel J, Clay D, Devocelle A, Croce M, Ferrini S, Chouaib S, Vazquez A, Charpentier B, Camussi G, Azzarone B, Eid P (2011) Differentiation therapy: targeting human renal cancer stem cells with interleukin 15. J Natl Cancer Inst 103(24): 1884-1898

96. Shanmugham LN, Petrarca C, Frydas S, Donelan J, Castellani ML, Boucher W, Madhappan B, Tete S, Falasca K, Conti P, Vecchiet J (2006) IL-15 an immunoregulatory and anti-cancer cytokine. Recent advances. J Exp Clin Cancer Res 25(4):529536

97. Smith LM, Nesterova A, Ryan MC, Duniho S, Jonas M, Anderson M, Zabinski RF, Sutherland MK, Gerber HP, Van Orden KL, Moore PA, Ruben SM, Carter PJ (2008) CD133/prominin-1 is a potential therapeutic target for antibody-drug conjugates in hepatocellular and gastric cancers. Br J Cancer 99(1):100-109

98. Jin L, Hope KJ, Zhai Q, Smadja-Joffe F, Dick JE (2006) Targeting of CD44 eradicates human acute myeloid leukemic stem cells. Nat Med 12(10):1167-1174

99. Toole BP (2009) Hyaluronan-CD44 interactions in cancer: paradoxes and possibilities. Clin Cancer Res 15(24):7462-7468

100. Riquelme PA, Drapeau E, Doetsch F (2008) Brain microecologies: neural stem cell niches in the adult mammalian brain. Philos Trans R Soc Lond B Biol Sci 363(1489):123-137

101. Calabrese C, Poppleton H, Kocak M, Hogg TL, Fuller C, Hamner B, Oh EY, Gaber MW, Finklestein D, Allen M, Frank A, Bayazitov IT, Zakharenko SS, Gajjar A, Davidoff A, Gilbertson RJ (2007) A perivascular niche for brain tumor stem cells. Cancer Cell 11(1):69-82 
102. Bao S, Wu Q, Sathornsumetee S, Hao Y, Li Z, Hjelmeland AB, Shi Q, McLendon RE, Bigner DD, Rich JN (2006) Stem cell-like glioma cells promote tumor angiogenesis through vascular endothelial growth factor. Cancer Res 66(16):7843-7848

103. Nian WQ, Chen FL, Ao XJ, Chen ZT (2011) CXCR4 positive cells from Lewis lung carcinoma cell line have cancer metastatic stem cell characteristics. Mol Cell Biochem 355(1-2):241-248

104. Jung MJ, Rho JK, Kim YM, Jung JE, Jin YB, Ko YG, Lee JS, Lee SJ, Lee JC, Park MJ (2012) Upregulation of CXCR4 is functionally crucial for maintenance of stemness in drug-resistant non-small cell lung cancer cells. Oncogene. doi:10.1038/ onc.2012.37 [Epub ahead of print]

105. Burger JA, Stewart DJ, Wald O, Peled A (2011) Potential of CXCR4 antagonists for the treatment of metastatic lung cancer. Expert Rev Anticancer Ther 11(4):621-630

106. Jin L, Lee EM, Ramshaw HS, Busfield SJ, Peoppl AG, Wilkinson L, Guthridge MA, Thomas D, Barry EF, Boyd A, Gearing DP, Vairo G, Lopez AF, Dick JE, Lock RB (2009) Monoclonal antibody-mediated targeting of CD123, IL-3 receptor alpha chain, eliminates human acute myeloid leukemic stem cells. Cell Stem Cell 5(1):31-42

107. Todaro M, Alea MP, Di Stefano AB, Cammareri P, Vermeulen L, Iovino F, Tripodo C, Russo A, Gulotta G, Medema JP, Stassi G (2007) Colon cancer stem cells dictate tumor growth and resist cell death by production of interleukin-4. Cell Stem Cell 1(4):389-402

108. Todaro M, Perez Alea M, Scopelliti A, Medema JP, Stassi G (2008) IL-4-mediated drug resistance in colon cancer stem cells. Cell Cycle 7(3):309-313

109. Schatton T, Murphy GF, Frank NY, Yamaura K, Waaga-Gasser AM, Gasser M, Zhan Q, Jordan S, Duncan LM, Weishaupt C, Fuhlbrigge RC, Kupper TS, Sayegh MH, Frank MH (2008) Identification of cells initiating human melanomas. Nature 451 (7176):345-349

110. Lou H, Dean M (2007) Targeted therapy for cancer stem cells: the patched pathway and $A B C$ transporters. Oncogene 26(9):1357-1360

111. Botrugno OA, Santoro F, Minucci S (2009) Histone deacetylase inhibitors as a new weapon in the arsenal of differentiation therapies of cancer. Cancer Lett 280(2):134-144
112. Goldsmith KC, Liu X, Dam V, Morgan BT, Shabbout M, Cnaan A, Letai A, Korsmeyer SJ, Hogarty MD (2006) BH3 peptidomimetics potently activate apoptosis and demonstrate single agent efficacy in neuroblastoma. Oncogene 25(33):4525-4533

113. Altieri DC (2003) Validating survivin as a cancer therapeutic target. Nat Rev Cancer 3(1):46-54

114. Hu T, Liu S, Breiter DR, Wang F, Tang Y, Sun S (2008) Octamer 4 small interfering RNA results in cancer stem cell-like cell apoptosis. Cancer Res 68(16):6533-6540

115. Mocellin S, Mandruzzato S, Bronte V, Lise M, Nitti D (2004) Part I: vaccines for solid tumours. Lancet Oncol 5(11):681-689

116. Banchereau J, Palucka AK, Dhodapkar M, Burkeholder S, Taquet N, Rolland A, Taquet S, Coquery S, Wittkowski KM, Bhardwaj N, Pineiro L, Steinman R, Fay J (2001) Immune and clinical responses in patients with metastatic melanoma to CD34(+) progenitor-derived dendritic cell vaccine. Cancer Res 61 (17):6451-6458

117. Panelli MC, Wunderlich J, Jeffries J, Wang E, Mixon A, Rosenberg SA, Marincola FM (2000) Phase 1 study in patients with metastatic melanoma of immunization with dendritic cells presenting epitopes derived from the melanoma-associated antigens MART-1 and gp100. J Immunother 23(4):487-498

118. Morrison BJ, Schmidt CW, Lakhani SR, Reynolds BA, Lopez JA (2008) Breast cancer stem cells: implications for therapy of breast cancer. Breast Cancer Res 10(4):210

119. Xu Q, Liu G, Yuan X, Xu M, Wang H, Ji J, Konda B, Black KL, Yu JS (2009) Antigen-specific T-cell response from dendritic cell vaccination using cancer stem-like cell-associated antigens. Stem Cells 27(8):1734-1740

120. Mori T, Nishizawa S, Hirohashi Y, Torigoe T, Tamura Y, Takahashi A, Kochin V, Fujii R, Kondo T, Greene MI, Hara I, Sato N (2010) Efficiency of G2/M-related tumor-associated antigen-targeting cancer immunotherapy depends on antigen expression in the cancer stem-like population. Exp Mol Pathol 92(1):27-32

121. Rahman M, Deleyrolle L, Vedam-Mai V, Azari H, Abd-ElBarr M, Reynolds BA (2011) The cancer stem cell hypothesis: failures and pitfalls. Neurosurgery 68(2):531-545, discussion 545 